\title{
Criminal liability for tobacco corporations and executives
}

\author{
Kelsey Romeo-Stuppy (ㄱ) , ${ }^{1}$ Emmanuelle Béguinot, ${ }^{2}$ Wanda De Kanter ${ }^{3}$
}

${ }^{1}$ Action on Smoking and Health, Washington, DC, USA

${ }^{2}$ French National Committee Against Tobacco (CNCT), Paris, France

${ }^{3}$ Smoking Prevention Youth, Amsterdam, The Netherlands

\section{Correspondence to}

Kelsey Romeo-Stuppy, Action on Smoking and Health, Washington, DC 20036, USA; romeo-stuppyk@ash.org

Check for updates

(C) Author(s) (or their employer(s)) 2022. No commercial re-use. See rights and permissions. Published by BMJ.

To cite: Romeo-Stuppy K, Béguinot $\mathrm{E}$, De Kanter W. Tob Control

2022:31:355-357
While a criminal case against the tobacco industry sounds sensational, the suggestion that tobacco companies could face criminal liability for their actions is neither unprecedented nor groundbreaking. A criminal case against the tobacco industry was considered by the drafters of the Framework Convention on Tobacco Control, who encouraged parties to use their laws that deal with criminal liability under Article $19 .^{1}$

Courts have considered the possibility of criminal charges as well. The highest court in at least one American state described the tobacco industry's history of marketing and promotional schemes as 'extraordinarily reprehensible', and emphasised the criminal implications of the harms caused by this industry's actions. ${ }^{2}$ The Oregon Supreme Court not only discussed 'the possibility of severe criminal sanctions, both for the individual who participated and for the corporation generally', but stressed that these actions could 'constitute at least seconddegree manslaughter' under Oregon law. ${ }^{2}$ Homicide laws in jurisdictions around the world could be similarly interpreted and applied.

A criminal case is different from civil litigation in many ways. Notably, a criminal case in most countries must be brought by a government entity, usually a public prosecutor. ${ }^{3}$ Prosecutors are the 'gatekeepers' of criminal justice, ${ }^{3}$ and therefore must be convinced to bring a criminal prosecution against a tobacco corporation or executive. Furthermore, while a victory in a civil case is an award of money to the injured party ${ }^{4}$ (which the tobacco industry easily pays and goes back to business as usual), a criminal case could result in fines, court orders, and possibly even dissolution of the corporation or jail time for the executives. ${ }^{5}$

Civil litigation has long been an impactful tool against the industry, but regrettably, the tobacco industry is still winning at least $25 \%$ of civil cases in the USA. ${ }^{6}$ A criminal case against the tobacco industry can help delegitimise the industry, make it harder for them to recruit top talent, have a deterrent effect, and allow anti-tobacco groups and governments to learn more about the harms perpetuated by the industry through the discovery process. In short, a criminal case is another potential tool in the arsenal against Big Tobacco.

\section{FROM THEORY INTO PRACTICE}

In the past few years, a criminal case against the tobacco industry has jumped from theory into practice. Criminal cases have been initiated in both the Netherlands and France. These cases provide proof of concept, and pave the way for criminal cases in other jurisdictions.

\section{The Dutch experience}

In the world's first example of a potential criminal case against tobacco manufacturers, the Dutch group Sick of Smoking encouraged a prosecutor to bring criminal charges against four tobacco corporations (Philip Morris International, British American Tobacco, Japan Tobacco International and Imperial Tobacco Benelux) for fraud, manslaughter and attempted murder. ${ }^{7}$

Although the advocacy in this case was initiated by a private group, the public prosecutor must be the one to officially bring a criminal case in the Netherlands. The case was submitted to the Public Prosecution Service on 29 September 2016 by Dutch criminal lawyer Bénédicte Ficq on behalf of two lung patients, Anne Marie van Veen and Lia Breed, and the Youth Smoking Prevention Foundation. ${ }^{8}$ Both women have since passed away due to their tobacco-induced diseases.

The proposed charges were attempted murder, manslaughter, aggravated assault and forgery by an industry that knowingly makes its cancer-causing tobacco products extremely addictive. ${ }^{10}$ In addition, the case alleged that cigarettes were modified by the manufacturers in such a way that the official measuring method for the content of tar, nicotine and carbon monoxide in cigarettes as prescribed by EU law was manipulated. ${ }^{10}$ As a result, smokers ingest more toxins than the legal maximum amounts. $^{11}$

To generate as much public support as possible, a grassroots movement called Sick of Smoking was formed. Ultimately, more than 24000 people endorsed the campaign to hold the tobacco industry to account. ${ }^{8}$ Many organisations joined the indictment, including hospitals, professional organisations, the Dutch Cancer Society, Lung Foundation Netherlands and the municipality of Amsterdam. ${ }^{12}$ Together, they represented over 1 million people.

After careful consideration, the public prosecutor decided not to proceed. The plaintiffs disagreed and appealed to ask the judge to order the Public Prosecution Service to prosecute. ${ }^{12}$ In the end, however, the court did not find legal grounds for the challenge. The judge agreed that the arguments of the plaintiffs were correct, but that the solution should be sought through the legislature, given that tobacco is a legal product. ${ }^{13}$

This action generated an enormous amount of publicity and contributed substantially to the awareness that smoking is an addiction and not a 
free choice. A study commissioned by the Dutch Cancer Society in May 2018 found that a majority (61\%) of the Dutch population think it is right that cigarette manufacturers have been called to account. ${ }^{19}$ The Dutch experience provides an excellent illustration of how a case against the tobacco industry can be a communications and education victory, even if the case itself is not victorious in court.

\section{The French experience}

Over the past few decades, the Comité National Contre le Tabagisme (National Committee for Tobacco Control or CNCT) has launched a number of legal actions against the tobacco industry. ${ }^{15}$ The tobacco industry has frequently violated the Public Health Code in France, especially through non-compliance with the ban on advertising, promotion and sponsorship, and CNCT has brought numerous criminal cases against them under this law. ${ }^{16}$

More recently, the CNCT has initiated procedures to challenge the liability of tobacco manufacturers under criminal law, not a criminal proceeding under the Public Health Code. These procedures involve both the responsibility of the corporation (a legal 'person'), and also the responsibility of a natural person through the company's CEO. ${ }^{17}$ The complaint asserts that Philip Morris was being deceptive by introducing micro-perforations in cigarette filters which falsified the measurements conducted by the National Testing Laboratory, which intends to control the content of tar, carbon monoxide and nicotine in cigarettes. ${ }^{17}$ The goal of these procedures is to hold these manufacturers responsible for endangering the life of others.

On 5 April 2018, the National Committee for Tobacco Control filed a complaint based on these facts, and later became a civil party. ${ }^{18}$ In France, a criminal petition can be filed with a civil claim (as by CNCT), ${ }^{19}$ and investigations are often handled by a judge or magistrate, who can order a prosecutor to take action. ${ }^{20}$

A judicial investigation was initiated, however, on 19 November 2019, the deputy prosecutor requested the dismissal of the complaint, ${ }^{17}$ arguing that an association like CNCT could not claim to be exposed to a risk against its physical integrity and therefore could not make a claim for a personal injury. The complaint was declared inadmissible.

As a result, a new complaint was filed, this time by an individual, Mrs X, with similar facts and legal complaints. ${ }^{18}$ The procedure has only just begun, but hopefully the court will agree with the complaint and view this as a criminal act by Philip Morris.

\section{Criminal liability for other corporations}

While there has yet to be a criminal conviction for tobacco executives, criminal liability for corporations and their officers is a concept that is gaining momentum around the world, in many varied disciplines. This includes criminal liability for products that, like tobacco, are not in themselves illegal or banned, as illustrated by several examples below.

In the case of climate change, many advocates are now pursuing legal remedies, including criminal charges, that require corporate polluters to pay restitution, ${ }^{21}$ cease and desist or drastically alter their actions, ${ }^{22}$ and occasionally even serve time in jail. $^{23}$

Recently, housing authorities ${ }^{24}$ around the world have been criminally charged when buildings have proven to be unsafe. The fire in Grenfell towers in England resulted in a manslaughter investigation, with several people facing jail time. ${ }^{25}$ Manslaughter charges are being considered in an apartment building collapse in
France $^{24}$ and police are investigating the recent Surfside Condo collapse in the USA as a homicide. ${ }^{26}$

Perhaps the most precise parallel is around opioid litigation, as criminal charges have been levied against the manufacturers of potentially lethal products. ${ }^{27}$ In another unfortunate similarity to tobacco, US-based pharma companies have exported their dangerous products around the world. ${ }^{28}$ The legal system has caught up quickly and criminal courts in both the USA ${ }^{27}$ and Italy $^{29}$ are being used to stop the opioid epidemic.

One specific example comes from a US case on food safety. In 2008-2009, there was a deadly outbreak of Salmonella infections; as many as 20000 people may have been sickened, and 9 people were killed. Investigation eventually linked the infections to contaminated peanut butter ${ }^{30}$ which had been befouled by rodent droppings, dead insects and a leaking roof. ${ }^{30}$ The former CEO was found guilty of knowingly selling tainted peanut butter and sentenced to 28 years in prison. ${ }^{31}$

There are many similarities between tobacco and these cases. In the peanut butter case, the opioid cases, and Big Tobacco, the corporations knowingly distributed a potentially toxic product. In the building cases, as with tobacco, ${ }^{32}$ corporations either ignored or concealed danger.

However, there are important differences as well. The peanut butter case and many of the opioid cases were brought under specific US federal laws, for example, the Food, Drug, and Cosmetic Act, ${ }^{33}$ instead of state or federal criminal law. Tobacco laws do not have an equivalent criminal component in the USA, or in many countries. The building safety cases do not have to contend with questions of addiction or even consent, making it virtually impossible to argue fault on the part of the victims, as has frequently been alleged in tobacco litigation. ${ }^{34}$

Despite the legal differences, these cases provide instructive examples for a criminal case against the tobacco industry or its executives, and also perhaps illustrate a willingness for judicial systems to punish corporate misdeeds more fervently than in the past.

\section{CONCLUSION}

Many of the tools tobacco control advocates use to move towards a world free from tobacco are legislative-for example, sinking lid licensing or tobacco-free generation proposals. Pursuing criminal liability brings in not only the judicial system, but the criminal justice system, which has been underused in public health and tobacco control. It is a potential work around in a legislative system that may not have the political will (or as is evidenced by the Netherlands, it could generate political will) or support to implement progressive tobacco control policies. Criminal liability is not the only path towards a tobacco endgame, but by further delegitimising the industry, it is one way to accelerate progress towards the end of the tobacco epidemic.

\section{Twitter Kelsey Romeo-Stuppy @AshOrg}

Contributors All authors contributed to the drafting of this article.

Funding The authors have not declared a specific grant for this research from any funding agency in the public, commercial or not-for-profit sectors.

Competing interests None declared.

Patient consent for publication Not required.

Ethics approval This study does not involve human participants.

Provenance and peer review Commissioned; externally peer reviewed.

ORCID iD

Kelsey Romeo-Stuppy http://orcid.org/0000-0002-6961-8031 


\section{REFERENCES}

1 World Health Organization. Framework convention on tobacco control, article 19, 2003. Available: http://www.who.int/fctc/en/

2 US Law. Williams V. Philip Morris Inc 127 P.3d 1165. Supreme Court of the state of Oregon, 2006: 1176-7.

3 United Nations Office on Drugs and Crime. General issues. Public prosecutors as the 'gate keepers' of criminal justice. Available: https://www.unodc.org/e4j/en/crimeprevention-criminal-justice/module-14/key-issues/2-general-issues-public-prosecutorsas-the-gate-keepers-of-criminal-justice.html

4 WHO FCTC. Article 19 civil liability toolkit. Available: https://untobaccocontrol.org/ impldb/tobacco-control-toolkit/\#/scenario/1

5 United States Sentencing Commission. Sentencing guidelines. Available: https://www. ussc.gov/guidelines/2018-guidelines-manual-annotated

6 Carrier J, Post W. One final look inside the archive that exposed big tobacco. Available: https://www.washingtonpost.com/outlook/minnesota-tobacco-document-depository/ 2021/08/25/cdc1ecfc-050c-11ec-a654-900a78538242_story.html

7 Netherlands Public Prosecution Service. No further investigation into tobacco industry. Available: https://www.prosecutionservice.nl/latest/news/2018/02/22/no-furtherinvestigation-into-the-tobacco-industry

8 Sick of smoking. Case against the tobacco industry: an overview, 2021. Available: https://sickofsmoking.nl/en/rechtzaken/case-against-the-tobacco-industry-anoverview/

9 Tabaknee. Anne Marie van Veen continued to fight against the murderous tobacco industry until the end. Available: https://www.tabaknee.nl/nieuws/item/ 1700-anne-marie-van-veen-bleef-tot-het-eind-strijden-tegen-moorddadigetabaksindustrie

10 Sick of smoking. attempted murder, manslaughter, Grievous bodily harm and falsification of documents. Available: https://sickofsmoking.nl/en/rechtzaken/ attempted-murder-manslaughter-grievous-bodily-harm-and-falsification-documents/

11 Rijksinstituut voor Volksgezondheid en milieu (Dutch National Institute for health and the environment). RIVM measures much higher levels of TAR, nicotine and carbon monoxide in cigarettes. Available: https://www.rivm.nl/en/news/rivm-measures-muchhigher-levels-of-tar-nicotine-and-carbon-monoxide-in-cigarettes

12 The Hague Court of appeal decision, case K181220231. Available: https://2bark924 ef5o2dk1z21reqtf-wpengine.netdna-ssl.com/wp-content/uploads/2019/02/Beedigdevertaling-Hof.pdf

13 Insider, Dutch Court Refuses to order criminal tobacco investigation, 2021. Available: https://www.insider.com/ap-dutch-court-refuses-to-order-criminal-tobaccoinvestigation-2018-12

14 Action on smoking and health. update: Dutch criminal case against the tobacco industry, 2021. Available: https://ash.org/update-dutch-criminal-case2019/

15 Campaign for tobacco free kids. tobacco control laws: country: France, 2021. Available: https://www.tobaccocontrollaws.org/litigation/advancedsearch/?country= France

16 Numerous examples. see for example- non-smokers' rights association V. British American tobacco, France, 2012. Available: https://www.tobaccocontrollaws.org/ litigation/advancedsearch/?country=France

17 Action on smoking and health. resources: criminal liability for tobacco executives, 2021. Available: https://ash.org/liabilityresources/

18 Comité national Contre Le Tabagisme. Filtergate: opening of a preliminary investigation, 2021. Available: https://cnct.fr/ressource/communiques/trous-filtresenquete-preliminaire/
19 French code of criminal procedure. Article 85. Available: https://www.legislationline. org/download/id/6381/file/France_CPC_am2006_en.pdf

20 French code of criminal procedure. Article 86. Available: https://www.legislationline. org/download/id/6381/file/France_CPC am2006 en.pdf

21 Environmental Protection Agency. Major criminal cases, 2017. Available: https://www epa.gov/enforcement/2017-major-criminal-cases

22 Milieudefensie vs. Royal Dutch Shell, Zoekresultaat - inzien documentECLI:NL:RBDHA 2021. Available: https://uitspraken.rechtspraak.nl/inziendocument?id=ECLI:NL: RBDHA:2021:5339

23 United States department of justice. Tonawanda coke and manager Sentenced fo Violating the clean air act and resource conservation and recovery act. available: 2021. Available: https://www.justice.gov/opa/pr/tonawanda-coke-and-managersentenced-violating-clean-air-act-and-resource-conservation-and

24 Press AF. The local. French housing authority charged with manslaughter after building collapse that killed eight, 2021. Available: https://www.thelocal.fr/20201104/frenchhousing-authority-charged-with-manslaughter-after-building-collapse-that-killedeight/

25 Booth R. The Guardian. People who worked on Grenfell Tower 'could face life sentences', 2021. Available: https://www.theguardian.com/uk-news/2020/jan/30/ people-who-worked-on-grenfell-tower-could-face-life-sentences

26 Wamsley L. Npr. inquiries into what went wrong in Surfside could take years to complete, 2021. Available: https://www.npr.org/sections/live-updates-miami-areacondo-collapse/2021/06/28/1010964005/investigations-into-what-caused-thesurfside-condos-collapse-have-already-begun

27 United States Department of Justice, Office of Public Affairs. Opioid manufacturer Purdue pharma Pleads guilty to fraud and Kickback Conspiracies, 2021. Available: https://www.justice.gov/opa/pr/opioid-manufacturer-purdue-pharma-pleads-guiltyfraud-and-kickback-conspiracies

28 Humphreys K, Caulkins J, Felbab-Brown VB. Order from chaos: what the US and Canada can learn from other countries to combat the opioid crisis. Available: https:// www.brookings.edu/blog/order-from-chaos/2020/01/13/what-the-us-and-canadacan-learn-from-other-countries-to-combat-the-opioid-crisis/

29 Galofaro C, D'Emilio F. Chicago Tribune. 'Pain League' with Purdue Pharma links allegedly pushed opioids in Italy, 2021. Available: https://www.chicagotribune.com/ business/ct-biz-oxycontin-purdue-pharma-italy-20190529-story.html

30 Bever L. Washington post. former peanut plant executive faces life sentence for lethal Salmonella coverup, 2021. Available: https://www.washingtonpost.com/news/ morning-mix/wp/2015/07/24/former-peanut-plant-executive-faces-life-sentence-forselling-salmonella-tainted-food/

31 Charles D. Npr. peanut Exec gets 28 years in prison for deadly Salmonella outbreak, 2021. Available: https://www.npr.org/sections/thesalt/2015/09/21/442335132/ peanut-exec-gets-28-years-in-prison-for-deadly-salmonella-outbreak

32 United States V. Phillip Morris, 449 f. Supp. 2D 1 (D.D.C.2006)., 2006. Available: https://www.publichealthlawcenter.org/sites/default/files/resources/doj-final-opinion. pdf

33 United States Department of Justice, Office of Public Affairs. Former peanut company president receives largest criminal sentence in food safety case; two others also Sentenced for their roles in Salmonella-Tainted peanut product outbreak, 2021. Available: https://www.justice.gov/opa/pr/former-peanut-company-president-receives largest-criminal-sentence-food-safety-case-two

34 Player T. After the fall: the cigarette papers, the global settlement, and the future of tobacco litigation, South Carolina law review 49 (2), 2021. Available: https:// scholarcommons.sc.edu/cgi/viewcontent.cgi?article=3267\&context=sclr 